\title{
AKTIVITAS ANTIOKSIDAN DAN ANTIBAKTERI HIDROLISAT PROTEIN HASIL FERMENTASI TELUR IKAN CAKALANG
}

\author{
Rifki Prayoga Aditia ${ }^{\star}$, Desniar, Wini Trilaksani \\ Departemen Teknologi Hasil Perairan Fakultas Perikanan dan Ilmu Kelautan \\ Institut Pertanian Bogor, Kampus IPB Darmaga, Jalan Agatis, Bogor 16680 Jawa Barat \\ Telepon (0251) 8622909-8622906, Faks. (0251) 8622915 \\ *Korespodensi: rifki.prayoga211@gmail.com \\ Diterima: 5 Desember 2017/ Disetujui: 29 Maret 2018
}

Cara sitasi: Aditia RP, Desniar, Trilaksani W. 2018. Aktivitas antioksidan dan antibakteri hidrolisat protein hasil fermentasi telur ikan cakalang. Jurnal Pengolahan Hasil Perikanan Indonesia. 21(1): 1-12.

\begin{abstract}
Abstrak
Telur ikan cakalang sebagai hasil samping pengolahan ikan asap potensial dimanfaatkan sebagai hidrolisat protein. Hidrolisis menggunakan fermentasi bakteri diharapkan menghasilkan peptida bioaktif yang bersifat antioksidan dan antibakteri pada hidrolisat protein telur ikan cakalang. Penelitian ini bertujuan menentukan aktivitas antioksidan dan antibakteri dari hidrolisat protein hasil fermentasi telur ikan cakalang. Pembuatan hidrolisat protein menggunakan 3 perlakuan fermentasi yaitu fermentasi spontan (FS), fermentasi menggunakan starter tunggal Lactobacillus plantarum SK 5 (FL) dan fermentasi menggunakan bakteri endogenous serta ditambah bakteri $L$. plantarum SK 5 (FSL). Hasil pengamatan menunjukkan bahwa total BAL (bakteri asam laktat) perlakuan FS meningkat hingga jam ke-48 fermentasi lalu menurun hingga akhir fermentasi. Perubahan total BAL yang cenderung statis terjadi pada perlakuan FSL, sedangkan pada perlakuan FL terjadi penurunan hingga jam ke-48 lalu cenderung statis hingga akhir fermentasi. Total mikroba aerob pada perlakuan FS dan FSL mengalami penurunan hingga jam ke-48 fermentasi, sedangkan pada perlakuan FL total mikroba aerob dari awal hingga akhir fermentasi terhitung sama dengan total BAL. Nilai absorbansi asam amino bebas pada perlakuan FS meningkat paling tinggi selama fermentasi. Aktivitas antioksidan dari hidrolisat protein perlakuan FS dan FSL mengalami penurunan seiring bertambahnya waktu fermentasi, sedangkan aktivitas antioksidan pada perlakuan FL tidak mengalami peningkatan setelah fermentasi. Aktivitas antibakteri tertinggi terjadi pada hidrolisat protein perlakuan FL pada konsentrasi 0,5 $\mathrm{mg} / \mu \mathrm{L}$ dengan lama waktu fermentasi $48 \mathrm{jam}$. Zona hambat yang terbentuk tergolong sedang.
\end{abstract}

Kata kunci: bioaktif, fermentasi spontan, L. plantarum SK (5), telur ikan.

\section{Antioxidant and Antibacterial Activity of Protein Hydrolysate from Fermented Cakalang Roe}

\begin{abstract}
Skipjack roe as a smoked fish industry by-product potentially can be used as protein hydrolysate. Hydrolysis using bacterial fermentation is expected to produce antioxidant and antibacterial peptides in skipjack roe protein hydrolysate. This study aimed to determine the antioxidant and antibacterial activity of protein hydrolysate from fermented cakalang roe. Production of protein hydrolysate used 3 fermentation treatments including spontaneous fermentation (FS), fermentation using single starter Lactobacillus plantarum SK (FL) and fermentation using endogenous bacteria plus L. plantarum SK (FSL). The result showed that LAB (lactic acid bacteria) numbers in spontaneous fermentation (FS) increased during 48 hours of fermentation and then decreased until the end of fermentation period. Changes in LAB numbers tend to be static occurs in the treatment of FSL, meanwhile the FL treatment decreased during 48 hours fermentation and tend to be static until the end of fermentation. Aerobic microbial numbers of FS and FSL treatments decreased during 48 hours of fermentation, meanwhile in the FL treatment from beginning to end fermentation was equal to LAB numbers. The absorbance value of free amino acids at FS treatment highly increased during fermentation. The antioxidant activity of protein hydrolysate of FS and FSL treatments decreased with the increasing of fermentation time, meanwhile antioxidant activity of FL treatment did not increase after fermentation. The highest antibacterial activity occurred in the FL treatment at concentration of $0,5 \mathrm{mg} / \mu \mathrm{L}$ after 48 hours of fermentation period. The formed inhibitory zone was classified as moderate.
\end{abstract}

Keywords: bioactive, fish roe, Lactobacillus plantarum SK (5), spontaneous fermentation. 


\section{PENDAHULUAN}

Produksi perikanan tangkap Indonesia pada tahun 2015 mencapai 6 juta ton, yang menempatkan Indonesia sebagai negara penghasil ikan terbesar kedua di dunia setelah Tiongkok. Komoditas utama yang memiliki kontribusi besar dalam industri perikanan tangkap Indonesia salah satunya adalah ikan cakalang (Katsuwonous pelamis). Jumlah tangkapan ikan ini mencapai 507 ribu ton atau $8,37 \%$ dari total produksi perikanan tangkap Indonesia (KKP 2015). Ikan jenis ini banyak dimanfaatkan untuk dijadikan bahan baku ikan kayu dan cakalang asap (Rahajeng 2012; Rieuwpassa et al. 2013).

Industri pengolahan ikan cakalang pada umumnya banyak menyisakan hasil samping berupa telur. Telur ikan yang dihasilkan dari industri pengolahan ikan cakalang banyak yang tidak termanfaatkan dan hanya terbuang begitu saja (Rieuwpassa et al. 2013). Telur ikan cakalang memiliki proporsi 1,5-3\% dari bobot tubuh serta memiliki kandungan protein yang cukup tinggi yaitu 20,5\% (Bledsoe et al. 2003; Intarasirisawat et al. 2010), sehingga perlu dilakukan upaya penanganan dan pemanfaatan telur ikan cakalang untuk meningkatkan nilai tambah, serta mengurangi dampak buruk terhadap lingkungan.

Telur ikan cakalang dapat dimanfaatkan menjadi hidrolisat protein ikan. Hidrolisat protein ikan merupakan produk yang dihasilkan dari penguraian protein ikan menjadi peptida sederhana dan asam amino melalui proses hidrolisis oleh enzim, asam, basa dan fermentasi (Kristinsson dan Rasco 2000; Jemil et al. 2014). Hidrolisis protein ikan secara enzimatis di antaranya berasal dari protein ikan lele dumbo (Salamah et al. 2012), ikan patin (Baehaki et al. 2018) serta jeroan ikan kakap putih (Nurhayati et al. 2014) yang menggunakan enzim papain, sedangkan hidrolisis secara fermentasi di antaranya dari kerang (Rajapakse et al. 2014) dan ikan sardin (Jemil et al. 2014).

Hidrolisat protein pada umumnya digunakan sebagai bahan tambahan pangan karena memiliki nilai gizi yang tinggi berupa asam amino, selain itu hidrolisat protein juga biasadimanfaatkansebagaiflavourenhancerdan bahan pengemulsi (Intarasirisawat et al. 2012;
Ovissipour et al. 2011). Hasil dari berbagai peneliti menyebutkan bahwa peptida yang terdapat dalam hidrolisat protein ternyata memiliki sifat bioaktif di antaranya yaitu bersifat antioksidan dan antibakteri (Najafian dan Babji 2011; Jemil et al. 2014).

Antioksidan dan antibakteri sangat berguna bagi bidang kesehatan dan pangan. Antioksidan sering digunakan dalam bentuk suplemen untuk membantu meningkatkan kesehatan tubuh dan mengurangi risiko terjadinya penyakit akibat radikal bebas misalnya kanker, diabetes, penuaan dini, dan jantung koroner. Antioksidan dan antibakteri juga digunakan sebagai pengawet untuk mencegah terjadinya oksidasi lemak serta membantu menghambat pertumbuhan bakteri penyebab kebusukan pada makanan (Najafian dan Babji 2011; Intarasirisawat et al. 2014). Hidrolisat protein yang memiliki aktivitas antioksidan juga bisa dijadikan sebagai alternatif pengganti antioksidan sintetik misalnya butylated hydroxyanisole (BHA), butylated hydroxytoluena (BHT) dan prophyl gallate (PG) yang diketahui mampu menginduksi kerusakan DNA serta menimbulkan toksik (Luo et al. 2012). Baehaki et al. 2015 melaporkan bahwa dalam $2 \mathrm{~mL}$ hidrolisat protein ikan patin yang dihidrolisis selama 6 jam menggunakan enzim papain konsentrasi $6 \%$ memiliki aktivitas penghambatan terhadap radikal DPPH sebesar $67,62 \%$

Fermentasi merupakan teknik tertua dalam pengawetan makanan, selain rendah biaya, fermentasi juga dapat menghasilkan produk yang memiliki nilai gizi tinggi (Phakde et al. 2014). Torino et al. (2012) menyatakan bahwa peptida bioaktif dapat dihasilkan melalui proses fermentasi. Rajapakse et al. (2014) melaporkan bahwa fermentasi saus kerang secara spontan memiliki aktivitas penghambatan terhadap radikal DPPH 72\% pada konsentrasi $200 \mu \mathrm{g} /$ $\mathrm{mL}$. Jemil et al. (2014) juga meneliti bahwa hidrolisat protein dari ikan sardin (Sardinella aurita) yang difermentasi menggunakan bakteri $B$. subtilis A26 memiliki aktivitas penghambatan terhadap bakteri $S$. aureus $(12,0 \pm 2,0 \mathrm{~mm})$ dan E. coli $(16,0 \pm 2,0 \mathrm{~mm})$ pada konsentrasi $0,2 \mathrm{mg} / \mu \mathrm{L}$. 
Torino et al. (2012) menyatakan bahwa hidrolisat protein hasil hidrolisis dengan fermentasi bisa menghasilkan peptida bioaktif yang sifatnya berbeda. Hal tersebut dipengaruhi oleh aktivitas dan spesivitas protease dari bakteri yang berperan selama fermentasi. Berdasarkan penelitian Kurniati et al. (2015) diketahui bahwa bakteri Lactobacillus plantarum SK (5) merupakan bakteri asam laktat hasil isolasi dari bekasam yang mampu menghasilkan enzim protease, sehingga berpotensi sebagai starter pada proses fermentasi. Berdasarkan hal tersebut, maka perlu dilakukan eksplorasi tentang potensi aktivitas antioksidan dan antibakteri dari hidrolisat protein yang dihasilkan dari fermentasi telur ikan cakalang baik secara spontan maupun menggunakan starter bakteri L. plantarum SK (5). Penelitian ini bertujuan menentukan aktivitas antioksidan dan antibakteri dari hidrolisat protein hasil fermentasi telur ikan cakalang.

\section{BAHAN DAN METODE Bahan dan Alat}

Bahan utama yang digunakan pada penelitian ini adalah telur ikan cakalang yang didapat dari hasil samping pengolahan ikan cakalang asap di Desa Galala Kota Ambon, Provinsi Maluku. Bakteri yang digunakan sebagai starter fermentasi yaitu L. plantarum SK (5) koleksi (Desniar 2012). Bahan lain yang digunakan meliputi deMan Rogosa and Sharpe Agar (MRSA), deMan Rogosa and Sharpe Broth (MRSB), Plate Count Agar (PCA), Mueller Hinton Agar (MHA), $\mathrm{CaCO}_{3}$, glukosa, $\mathrm{NaOH}$, phenolphthalein, dan 2,2-diphenyl-1-picrylhydrazyl (DPPH). Alat utama yang digunakan dalam penelitian ini adalah inkubator (IS900 Yamato), autoklaf (SM52 Yamato), oven drying sterilizer (SH62), homogenizer (Nissel AMS), centrifuge (himac CR 21G), spektrofotometer UV-Vis dan freeze dryer.

\section{Metode Penelitian Persiapan kultur bakteri}

Isolat L. plantarum SK (5) ditumbuhkan pada media MRSA. Isolat yang telah tumbuh diinokulasikan ke dalam $26 \mathrm{~mL}$ media MRSB dan diinkubasi pada suhu $37^{\circ} \mathrm{C}$ selama 16 jam, kemudian diambil 10\% dan ditumbuhkan pada kultur kerja MRSB sebanyak $260 \mathrm{~mL}$. Kultur kerja tersebut kemudian diinkubasi hingga jumlah sel mencapai $10^{8}-10^{9} \mathrm{CFU} / \mathrm{mL}$.

\section{Pembuatan hidrolisat protein telur ikan cakalang}

Pembuatan hidrolisat protein ikan mengacu kepada Torino et al. (2012). Telur ikan cakalang terlebih dahulu dihancurkan menggunakan blender. Telur ikan yang telah hancur ditambahkan akuades steril dengan perbandingan 1:2 (b/v) kemudian dihomogenkan dan cairan ditambahkan dengan glukosa steril sebanyak $1 \%(\mathrm{~b} / \mathrm{v})$. Bahan baku yang telah dipreparasi kemudian dimasukkan kedalam botol kaca steril dan selanjutnya dilakukan fermentasi. Proses fermentasi dilakukan dengan 3 perlakuan, yaitu: fermentasi spontan telur ikan cakalang (FS); fermentasi menggunakan bakteri endogenous telur ikan cakalang serta diberi penambahan starter bakteri L. plantarum SK (5) sebanyak $10 \%(\mathrm{v} / \mathrm{v})$ (FSL); dan fermentasi yang hanya menggunakan $10 \%(\mathrm{v} / \mathrm{v})$ starter bakteri L. plantarum SK (5) (FL). Khusus untuk perlakuan FL sampel telur ikan cakalang terlebih dahulu disterilisasi pada suhu $121^{\circ} \mathrm{C}$ selama 15 menit.

Fermentasi dilakukan selama 96 jam dan pengamatan dilakukan setiap 0,48 , dan 96 jam untuk melihat total mikroba aerob, total BAL, $\mathrm{pH}$ dan total asam tertitrasi. Proses fermentasi dihentikan dengan memanaskan sampel pada suhu $95^{\circ} \mathrm{C}$ selama 15 menit, kemudian sampel disentrifugasi dengan kecepatan $10.000 \mathrm{~g}$ selama 20 menit. Filtrat hasil sentrifugasi diuji kandungan asam amino bebasnya, selanjutnya filtrat dikeringkan menggunakan freeze dryer dan diuji aktivitas antioksidan dan antibakterinya.

\section{Total mikroba dan total BAL}

Pengujian total mikroba dan total BAL mengacu pada BSN 2006 modifikasi. Sampel sebanyak $10 \mathrm{~mL}$ dilarutkan ke dalam $90 \mathrm{~mL}$ BPW steril sehingga diperoleh sampel dengan pengenceran $10^{-1}$. Larutan dipipet sebanyak 1 $\mathrm{mL}$ dan dimasukkan ke dalam tabung reaksi yang berisi $9 \mathrm{~mL}$ larutan BPW steril untuk mendapatkan pengenceran $10^{-2}$, demikian 
seterusnya sampai pengenceran $10^{-8}$. Sampel sebanyak $1 \mathrm{~mL}$ masing-masing pengenceran dipipet dan dimasukkan ke dalam cawan petri steril, kemudian dituang $\pm 15 \mathrm{~mL}$ media PCA untuk pengujian total mikroba dan MRSA yang ditambah $\mathrm{CaCO}_{3} \quad 0,5 \%$ steril untuk pengujian total BAL. Cawan yang berisi media digoyang secara merata dan didiamkan, setelah itu cawan diinkubasi dengan posisi terbalik pada suhu $37^{\circ} \mathrm{C}$ selama 48 jam, khusus untuk media BAL diinkubasi dalam kondisi mikroaerofilik. Jumlah total bakteri dihitung (25-250 koloni) dan dinyatakan dalam CFU/ $\mathrm{mL}$. Rumus perhitungan yang digunakan adalah sebagai berikut:

$$
\mathrm{N}=\frac{\Sigma \mathrm{C}}{[(1 \times n 1)+(0,1 \times n 2)] \times(d)}
$$

$\mathrm{N}$ adalah jumlah koloni produk per $\mathrm{mL}$ atau koloni per g; $\Sigma \mathrm{C}$ adalah jumlah koloni pada semua cawan yang dihitung; $n 1$ adalah jumlah cawan pada pengenceran pertama yang dihitung; $n 2$ adalah jumlah cawan pada pengenceran kedua yang dihitung; $d$ adalah pengenceran pertama yang dihitung.

\section{Asam amino bebas}

Pengujian asam amino mengacu pada Wang (2009). Pereaksi terdiri dari 0,35 g ninhidrin dalam $100 \mathrm{~mL}$ etanol $95 \%$. Filtrat hasil sentrifugasi sebanyak $5 \mathrm{~mL}$ ditambah dengan $1 \mathrm{~mL}$ pereaksi ninhidrin di dalam tabung. Tabung ditutup rapat dengan parafilm, selanjutnya dipanaskan pada suhu 80-100 ${ }^{\circ} \mathrm{C}$ selama 4-7 menit hingga terbentuk warna ungu. Kadar asam amino bebas diketahui dengan spektrofotometer UV-vis pada panjang gelombang $570 \mathrm{~nm}$.

\section{Aktivitas Antioksidan Metode DPPH}

Pengujian aktivitas antioksidan mengacu pada Wu et al. (2003). Hidrolisat protein dilarutkan dalam pelarut akuades pada berbagai konsentrasi. Larutan hidrolisat protein sebanyak $2 \mathrm{~mL}$ direaksikan dengan $2 \mathrm{~mL}$ DPPH $0,15 \mathrm{mM}$ pada tabung reaksi. Campuran kemudian divortex dan diinkubasi pada suhu $37^{\circ} \mathrm{C}$ selama 30 menit, kemudian larutan diukur absorbansinya pada panjang gelombang $517 \mathrm{~nm}$. Absorbansi larutan blanko juga diukur untuk melakukan perhitungan persen inhibisi. Hasil pengukuran absorbansi dan untuk menentukan aktivitas antioksidan dinyatakan dalam rumus:

Inhibisi $(\%)=$ absorbansi blanko-absorbansi sampel absorbansi blanko $\times 100 \%$

Nilai konsentrasi sampel dan persen inhibisinya diplot masing-masing pada sumbu $\mathrm{x}$ dan $\mathrm{y}$ pada persamaan regresi linear. Persamaan regresi linear yang diperoleh digunakan untuk mencari nilai $\mathrm{IC}_{50}$ (Inhibitor Concentration 50\%).

\section{Aktivitas antibakteri}

Pengujian antibakteri mengacu pada Holo et al. 1991. Bakteri uji yaitu Staphylococcus aureus dan Escherichia coli diinokulasikan ke dalam media NB steril dan diinkubasi pada suhu $37^{\circ} \mathrm{C}$ selama 24 jam sampai OD mencapai 0,5-0,8. Sebanyak $20 \mu \mathrm{L}$ bakteri uji dimasukkan ke dalam $20 \mathrm{~mL}$ media MHA steril, kemudian media dituang ke dalam cawan steril secara aseptis. Media MHA yang telah memadat dilubangi menggunakan pipet tetes steril yang berdiameter $6 \mathrm{~mm}$. Hidrolisat protein konsentrasi 0,25 dan 0,5 $\mathrm{mg} / \mu \mathrm{L}$ dipipet ke dalam lubang sumur. Cawan diinkubasi pada suhu $37^{\circ} \mathrm{C}$ selama 6 jam, selanjutnya dilakukan pengukuran diameter zona hambat di sekeliling lubang.

\section{Analisis Data}

Data hasil penelitian diolah menggunakan Microsoft Excel. Data tersebut dianalisis secara deskriptif, disajikan dalam bentuk grafik, diagram dan tabel.

\section{HASIL DAN PEMBAHASAN Pertumbuhan dan Aktivitas Pengasaman oleh Bakteri Selama Fermentasi}

Pertumbuhan bakteri merupakan proses yang terdiri dari reaksi anabolisme dan katabolisme. Pertumbuhan bakteri umumnya terdiri dari fase adaptasi, fase log, fase stasioner dan fase kematian. Masing-masing fase yang terjadi menunjukkan perubahan aktivitas fisiologi sel di dalam media selama pertumbuhan (Maier et al. 2009). 
Hasil pertumbuhan dan aktivitas pengasaman oleh bakteri selama fermentasis dapat dilihat pada Tabel 1 .

Hasil pengamatan menunjukkan bahwa total BAL pada perlakuan FS mengalami pertumbuhan paling tinggi selama 48 jam, sedangkan pada perlakuan FSL dan FL perubahan total BAL cenderung statis dari awal hingga akhir fermentasi (Tabel 1). Pertumbuhan BAL yang cenderung statis pada perlakuan FSL dan FL disebabkan oleh adanya proses adaptasi yang dilakukan oleh bakteri L. plantarum SK (5) pada media pertumbuhan baru. Hal serupa juga terjadi pada penelitian Lee et al. (2016) bahwa terjadi pertumbuhan BAL yang statis selama fermentasi kedelai menggunakan starter bakteri L. plantarum. Pepper et al. (2008) menjelaskan bahwa proses adapatasi bakteri pada media baru dipengaruhi oleh faktor jumlah sel yang diinokulasikan, kondisi fisiologis dan morfologis bakteri, serta media kultivasi yang sesuai.

Populasi mikroba aerob dan populasi BAL pada perlakuan FL jumlahnya sama selama fermentasi (Tabel 1), karena bakteri yang terhitung sebagai total mikroba aerob dan total BAL adalah satu jenis bakteri yang sama yaitu $L$. plantarum SK (5). Total mikroba aerob pada perlakuan FS dan FSL pada jam ke-0 lebih tinggi dibandingkan dengan total BAL, namun setelah terjadi fermentasi selama 48 jam total mikroba aerob mengalami penurunan dan jumlahnya sama dengan total BAL (Tabel 1). Populasi mikroba aerob yang menurun mengindikasikan bahwa terjadi penghambatan pertumbuhan terhadap bakteri lain selain golongan BAL. Hasil ini juga didukung oleh Yin et al. (2002) bahwa selama fermentasi ikan makarel menggunakan starter bakeri L. plantarum terjadi penghambatan terhadap pertumbuhan bakteri Staphylococcus dan Pseudomonas. Shirai et al. (2000) menyatakan bahwa BAL memiliki kemampuan untuk mengubah glukosa menjadi asam organik misalnya asam laktat, asetat, suksinat dan propionat. Asam organik yang terakumulasi selama fermentasi akan berdampak pada penurunan $\mathrm{pH}$ lingkungan, sehingga akan menghambat pertumbuhan bakteri yang tidak tahan terhadap asam.

Total asam tertitrasi menunjukkan banyaknya asam organik yang terkandung dalam produk selama fermentasi. Total asam tertitrasi yang semakin meningkat selama fermentasi akan mengakibatkan penurunan nilai $\mathrm{pH}$. Nilai $\mathrm{pH}$ pada perlakuan FL menurun paling rendah dibandingkan perlakuan FS dan FSL yang diduga disebabkan adanya akumulasi asam organik berupa asam laktat yang berasal dari starter tunggal bakteri L. plantarum SK (5). Menurut Desniar (2012) bakteri L. plantarum SK (5) merupakan bakteri homofermentatif yang mampu memproduksi asam laktat secara dominan. Ross et al. (2002) menambahkan bahwa bakteri homofermentatif mampu mengubah lebih dari 90\% substrat gula menjadi asam laktat. Ray (2004) menyatakan bahwa asam laktat merupakan asam organik yang memiliki konstanta disosiasi ( $\mathrm{pKa}$ ) paling rendah diantara asam organik lain yang dihasilkan oleh BAL, semakin kecil nilai

Tabel 1 Perubahan total mikroba dan pengasaman selama fermentasi

(Table 1 Changes in total microbes and acidification during fermentation)

\begin{tabular}{cccccc}
\hline $\begin{array}{c}\text { Perlakuan } \\
\text { fermentasi/ } \\
\begin{array}{c}\text { Fermentation } \\
\text { treatment }\end{array}\end{array}$ & $\begin{array}{c}\text { Waktu fermentasi/ } \\
\text { Fermentation } \\
\text { period (jam/hours) }\end{array}$ & $\begin{array}{c}\text { Total BAL } \\
\text { (log CFU/mL) }\end{array}$ & $\begin{array}{c}\text { Total aerobic } \\
\text { microbial (log } \\
\text { CFU/mL) }\end{array}$ & $\begin{array}{c}\text { Total asam tertitrasi/ } \\
\text { Total acidified acid } \\
(\%)\end{array}$ & $\mathrm{pH}$ \\
\hline \multirow{2}{*}{ FS } & 0 & $5.77 \pm 0.29$ & $8.76 \pm 0.12$ & $0.87 \pm 0.05$ & $5.95 \pm 0.28$ \\
& 48 & $8.38 \pm 0.03$ & $8.36 \pm 0.13$ & $2.57 \pm 0.23$ & $4.65 \pm 0.05$ \\
& 96 & $7.26 \pm 0.08$ & $6.99 \pm 0.10$ & $2.06 \pm 0.16$ & $5.39 \pm 0.30$ \\
FSL & 0 & $8.18 \pm 0.11$ & $8.65 \pm 0.48$ & $1.06 \pm 0.03$ & $5.67 \pm 0.08$ \\
& 48 & $7.92 \pm 0.03$ & $7.91 \pm 0.06$ & $3.20 \pm 0.27$ & $4.24 \pm 0.06$ \\
& 96 & $7.97 \pm 0.27$ & $7.87 \pm 0.21$ & $2.72 \pm 0.11$ & $4.87 \pm 0.19$ \\
FL & 0 & $7.90 \pm 0.18$ & $8.09 \pm 0.10$ & $1.17 \pm 0.18$ & $5.60 \pm 0.10$ \\
& 48 & $6.82 \pm 0.17$ & $6.77 \pm 0.16$ & $3.96 \pm 0.32$ & $4.09 \pm 0.03$ \\
& 96 & $6.75 \pm 0.10$ & $6.67 \pm 0.21$ & $4.18 \pm 0.16$ & $4.08 \pm 0.03$ \\
\hline
\end{tabular}


pKa asam organik maka akan mengakibatkan semakin kuat kadar keasamannya.

\section{Aktivitas Penguraian Protein}

Fermentasi merupakan salah satu cara yang bisa digunakan untuk menghasilkan bioaktif peptida. Fermentasi melibatkan peran bakteri proteolitik dalam mengurai substrat protein menjadi bentuk yang lebih sederhana yaitu peptida dan asam amino. Aktivitas penguraian protein selama fermentasi dapat diketahui melalui uji ninhidrin. Wang (2009) menjelaskan bahwa prinsip dari pengujian ninhidrin yaitu melihat perubahan warna yang terjadi akibat reaksi ninhidrin dengan asam amino bebas yang semula berwarna kuning menjadi warna ungu, semakin pekat warna ungu yang dihasilkan menandakan semakin banyak asam amino bebas yang terurai selama fermentasi. Hasil uji asam amino bebas selama fermentasi disajikan pada Gambar 1.

Hasil pengamatan menunjukkan bahwa aktivitas penguraian protein tertinggi terjadi pada perlakuan FS yang ditandai dengan terjadinya peningkatan nilai absorbansi paling tinggi selama fermentasi (Gambar 1). Aktivitas penguraian protein yang terjadi dapat dikaitkan dengan aktivitas pertumbuhan bakteri selama fermentasi. Pertumbuhan BAL pada perlakuan FS mengalami peningkatan populasi tertinggi diantara perlakuan lain selama 48 jam fermentasi (Tabel 1), sehingga menyebabkan aktivitas proteolitik bakteri dalam memecah protein pada perlakuan FS menjadi semakin meningkat. Torino et al. (2012) melaporkan bahwa aktivitas proteolitik dari bakteri asam laktat dalam mengurai protein kacang lentil semakin meningkat seiring dengan bertambahnya jumlah sel bakteri dan aktivitas penguraiannya akan menurun ketika bakteri mulai memasuki fase stasioner.

Nilai absorbansi pada perlakuan FL tidak memperlihatkan adanya peningkatan selama fermentasi. Hal tersebut disebabkan oleh tidak terjadinya penguraian protein selama fermentasi karena bakteri L. plantarum SK (5) sedang mengalami fase adapatasi (Tabel 1), sehingga enzim proteolitik yang dihasilkan belum mampu mengurai protein telur ikan. Hal ini juga didukung oleh Kabadjova-Hristova et al. (2006) bahwa pada fase adaptasi aktivitas proteolitik yang dihasilkan bakteri Lactobacillus kefir DR22x sangat rendah yaitu sekitar $20 \mathrm{EU} / \mathrm{mL}$,

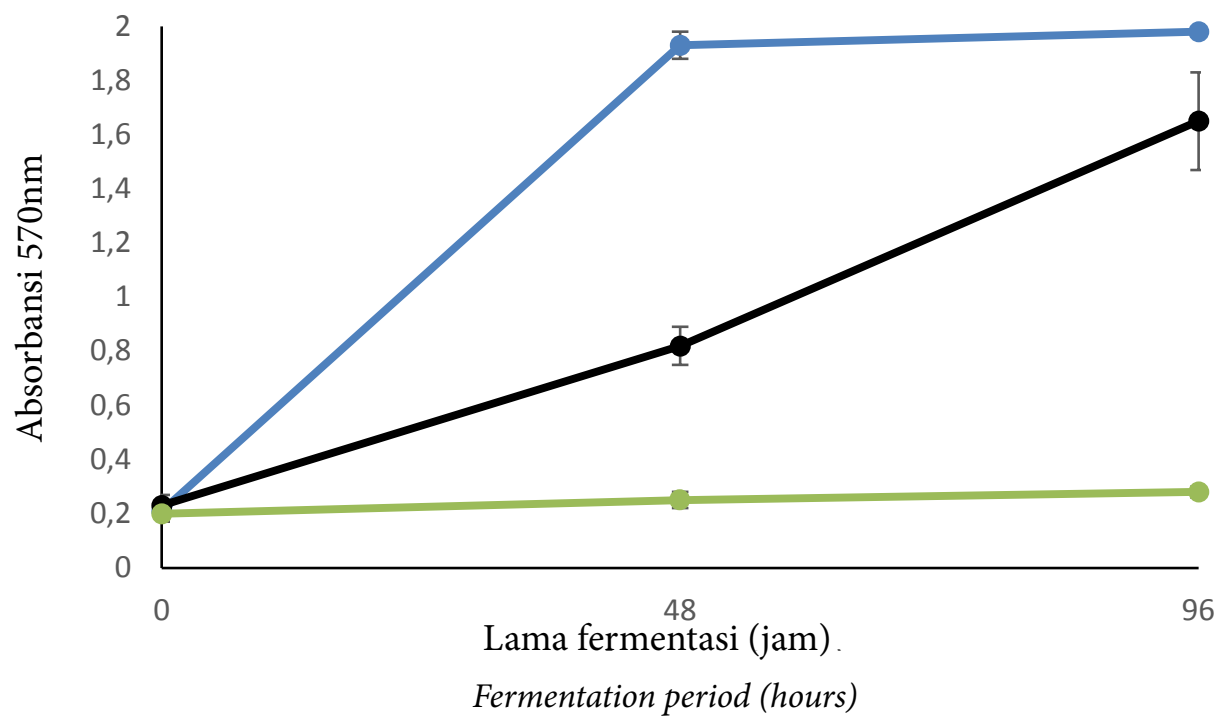

Gambar 1 Nilai absorbansi asam amino bebas selama fermentasi telur ikan cakalang pada perlakuan FS $(-)$, FSL $(-)$ dan FL $(-)$.

(Figure 1 Absorbance of free amino acids during fermentation of cakalang roe treatment FS (-), FSL (一) dan FL (-)). 
sedangkan pada fase eksponensial aktivitas proteolitik meningkat tajam hingga mencapai $550 \mathrm{EU} / \mathrm{mL}$.

\section{Aktivitas Antioksidan}

Pengujian aktivitas antioksidan dilakukan dengan metode DPPH (2,2-diphenyl-1-picrylhydrazyl). Parameter yang digunakan untuk menginterpretasikan hasil pengujian adalah nilai $\mathrm{IC}_{50}$ yang didefinisikan sebagai konsentrasi senyawa antioksidan yang menyebabkan hilangnya $50 \%$ aktivitas DPPH. Hasil pengujian aktivitas antioksidan hidrolisat protein telur ikan cakalang disajikan pada Gambar 2.

Hidrolisat protein dari perlakuan FS, FSL dan FL mengalami perbedaan aktivitas antioksidan setelah dilakukan fermentasi. Nilai $\mathrm{IC}_{50}$ hidrolisat protein perlakuan $\mathrm{FS}$ meningkat pada jam ke-48 fermentasi dan selanjutnya tidak terjadi perubahan pada akhir fermentasi. Nilai $\mathrm{IC}_{50}$ hidrolisat protein perlakuan FSL terus mengalami peningkatan dari awal hingga akhir fermentasi, sedangkan pada hidrolisat protein perlakuan FL tidak mengalami perubahan selama fermentasi. Menurut Torino et al. (2012) aktivitas antioksidan pada hidrolisat protein sangat dipengaruhi oleh jenis peptida yang terbentuk selama fermentasi, pembentukan peptida ini dipengaruhi oleh aktivitas dan spesivitas protease bakteri yang berperan dalam fermentasi. Wu et al. (2003) juga menyatakan bahwa berat molekul dan komposisi asam amino pada peptida yang terbentuk selama hidrolisis sangat mempengaruhi aktivitas antioksidan pada hidrolisat protein.

Aktivitas antioksidan yang dihasilkan oleh hidrolisat protein perlakuan FS, FSL dan FL masih lebih rendah dibandingkan dengan aktivitas antioksidan pada kontrol, yaitu asam askorbat yang memiliki nilai $\mathrm{IC}_{50}$ sebesar $0,016 \mathrm{mg} / \mathrm{mL}$. Aktivitas antioksidan hidrolisat protein pada penelitian ini masih lebih baik dibandingkan dengan hasil dari beberapa penelitian lain. Torino et al. (2014) melaporkan bahwa hidrolisat protein ikan sarden (Sardinella aurita) dan ikan pari (Dasyatis pastinaca) hasil fermentasi dengan bakteri Bacillus subtilis A26 memiliki IC $_{50}$ sebesar 4,04 $\mathrm{mg} / \mathrm{mL}$ dan $2,93 \mathrm{mg} / \mathrm{mL}$. Chalamaiah et al. (2015) juga melaporkan bahwa aktivitas antioksidan pada hidrolisat protein telur ikan mas (Cyprinus carpio) hasil hidrolisis dengan enzim pepsin memiliki $\mathrm{IC}_{50}$ sebesar 2,26 mg/mL.

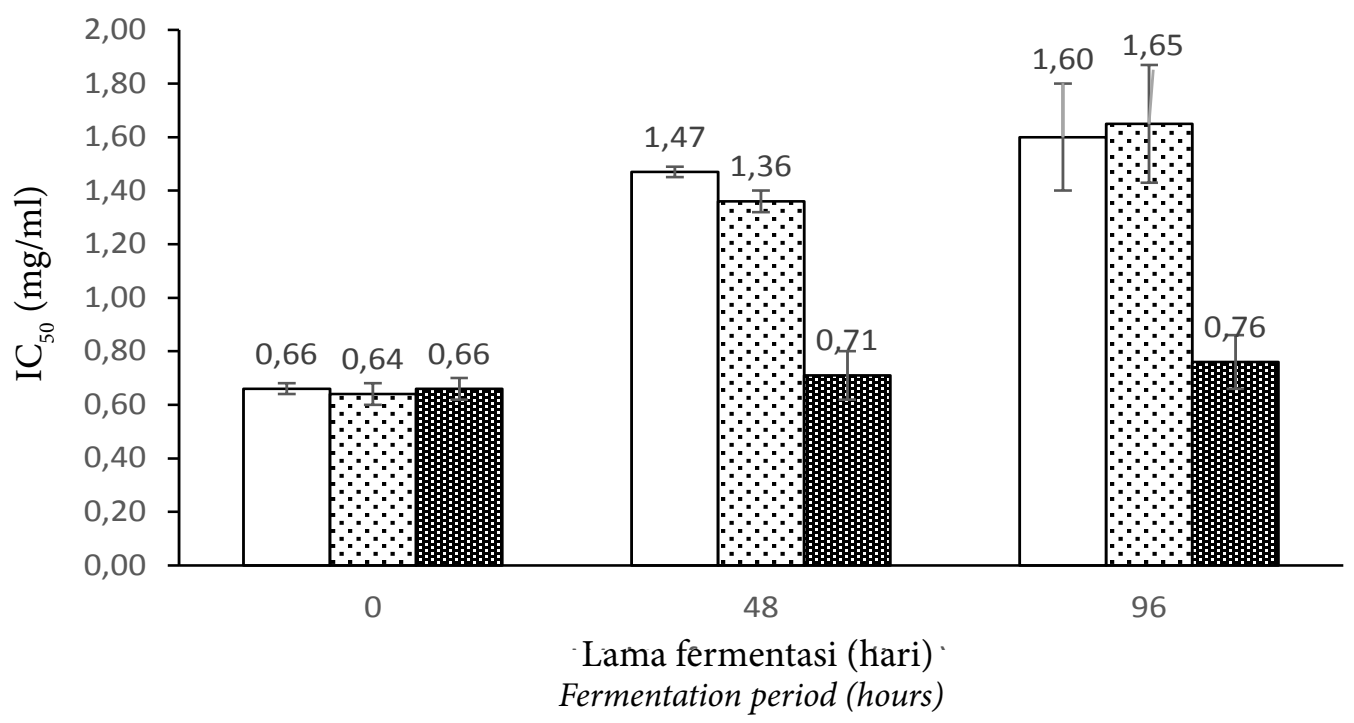

Gambar 2 Nilai $\mathrm{IC}_{50}$ hidrolisat protein telur ikan cakalang perlakuan FS ( $\square$ ), FSL ( $\left.\because\right)$, dan FL (III).

Figure $2 I_{50}$ value of protein hydrolysate of fermented cakalang roe treatment FS ( $\square$ ), FSL ( $\because$ ), and $F L$ (䧳). 
Nilai IC $_{50}$ pada hidrolisat protein perlakuan FS dan FSL semakin meningkat seiring bertambahnya waktu fermentasi (Gambar 2). Hal tersebut menandakan bahwa selama fermentasi terjadi penurunan aktivitas antioksidan pada hidrolisat protein. Samaranayaka (2010) menyatakan bahwa penurunan aktivitas antioksidan seiring bertambahnya waktu hidrolisis disebabkan olehrusaknyaurutan peptidaantioksidatifyang terbentuk pada tahap awal proses hidrolisis. Klompong et al. (2007) menambahkan bahwa perubahan ukuran peptida yang semakin mengecil seiring bertambahnya waktu hidrolisis juga bertanggung jawab terhadap penurunan aktivitas antioksidan dari hidrolisat protein. Hal tersebut dikuatkan oleh You et al. (2009) bahwa hidrolisat protein ikan loach (Misgurnus anguillicaudatus) yang didominasi oleh ikatan peptida dengan bobot molekul $<500 \mathrm{Da}$ memiliki aktivitas penghambatan terhadap radikal bebas DPPH lebih rendah dibandingkan dengan hidrolisat protein yang didominasi oleh ikatan peptida dengan bobot molekul 1.000-3.000 Da. Wu et al. (2003) juga melaporkan bahwa dari fraksi bobot molekul hidrolisat protein ikan makarel (Scomber austriasicus) diketahui bahwa peptida dengan bobot molekul 1400 Da memiliki aktivitas antioksidan lebih tinggi jika dibandingkan dengan peptida dengan bobot molekul 900 dan 200 Da.

Aktivitas antioksidan pada hidrolisat protein perlakuan FL tidak mengalami peningkatan setelah dilakukan fermentasi (Gambar 2). Hal tersebut terlihat dari nilai $\mathrm{IC}_{50}$ perlakuan $\mathrm{FL}$ yang tidak mengalami perubahan dari awal hingga akhir fermentasi. Keberadaan peptida antioksidatif dari hasil fermentasi sangat diharapkan karena dapat meningkatkan aktivitas antioksidan pada hidrolisat protein. Penguraian protein pada perlakuan FL tidak terjadi selama fermentasi (Gambar 1) menjadi penyebab tidak dihasilkannya peptida antioksidatif. Kim dan Kim (2007) menerangkan bahwa peptida antioksidatif terdiri dari 3-20 residu asam amino dan aktivitasnya tergantung pada komposisi asam amino penyusunnya. Udenigwe dan Aluko (2011) menyatakan bahwa asam amino yang memiliki aktivitas penghambatan tinggi terhadap radikal DPPH adalah jenis asam amino hidrofobik, aromatik dan asam.

Potensi aktivitas antioksidan
dari peptida bioaktif telah banyak
dilaporkan, tetapi mekanisme yang
tepat mendasari efek antioksidan dari peptida bioaktif belum sepenuhnya dijelaskan secara komprehensif. Menurut Chalamaiah et al. (2012) secara umum kemampuan peptida dalam menghambat radikal DPPH diakibatkan karena kemampuannya dalam mendonorkan elektron, sehingga membuat radikal bebas menjadi stabil. Molyneux (2004) menerangkan bahwa radikal DPPH yang mendapatkan donor elektron akan berubah menjadi bentuk tereduksinya yaitu 1,1-difenil-2-pikrilhidrazil (DPPH-H). Proses reduksi radikal DPPH menjadi DPPH-H ini ditandai dengan terjadinya perubahan warna dari ungu menjadi kuning pucat.

\section{Aktivitas Antibakteri}

Aktivitas antibakteri diuji menggunakan metode difusi sumur agar (agar well diffusion). Metode ini telah banyak digunakan dalam pengujian antibakteri karena relatif lebih sederhana dalam pengerjaannya. Aktivitas antibakteri dari hidrolisat protein telur ikan cakalang diuji terhadap dua jenis bakteri yaitu E. coli dan $S$. aureus yang masing-masing mewakili bakteri dari golongan Gram-negatif dan Gram-positif. Aktivitas antibakteri ditandai dengan terbentuknya zona hambat terhadap pertumbuhan bakteri di sekitar sumur. Hasil pengujian aktivitas antibakteri hidrolisat protein telur ikan cakalang dapat dilihat pada Tabel 2 .

Hasil pengujian aktivitas antibakteri menunjukkan bahwa penggunaan konsentrasi hidrolisat protein sangat berpengaruh terhadap zona hambat, semakin tinggi konsentrasi yang digunakan maka semakin luas zona hambat yang terbentuk (Tabel 2). Hal tersebut sesuai dengan pernyataan Pelczar dan Chan (2008) bahwa semakin tinggi konsentrasi suatu bahan antibakteri maka aktivitas antibakteri yang dihasilkan semakin kuat. Pan et al. (2009) mengkategorikan 
Tabel 2 Aktivitas antibakteri hidrolisat protein telur ikan cakalang (Table 2 Antibacterial activity of protein hidrolyzate cakalang roe)

\begin{tabular}{|c|c|c|c|c|c|}
\hline \multirow{3}{*}{$\begin{array}{l}\text { Bakteri uji/ } \\
\text { Bacterial test }\end{array}$} & \multirow{3}{*}{$\begin{array}{l}\text { Perlakuan fermen- } \\
\text { tasi/Fermentation } \\
\text { treatment }\end{array}$} & \multirow{3}{*}{$\begin{array}{c}\text { Konsentrasi / } \\
\text { Concentration } \\
(m g / \mu L)\end{array}$} & \multicolumn{3}{|c|}{ Zona hambat/Inhibitory zone $(\mathrm{mm})$} \\
\hline & & & \multicolumn{3}{|c|}{ Waktu fermentasi/Fermentation period (jam/hours) } \\
\hline & & & 0 & 48 & 96 \\
\hline \multirow{6}{*}{ E. coli } & \multirow{2}{*}{ FS } & 0.25 & - & - & - \\
\hline & & 0.50 & - & - & - \\
\hline & \multirow{2}{*}{ FL } & 0.25 & - & $2.5 \pm 0.7$ & $2.5 \pm 0.7$ \\
\hline & & 0.50 & - & $5.5 \pm 0.7$ & $5.5 \pm 0.7$ \\
\hline & \multirow{2}{*}{ FSL } & 0.25 & - & $1.0 \pm 0.0$ & - \\
\hline & & 0.50 & - & $4.5 \pm 0.7$ & $1.5 \pm 0.7$ \\
\hline \multirow{6}{*}{ S. aureus } & \multirow{2}{*}{ FS } & 0.25 & - & - & - \\
\hline & & 0.50 & - & - & - \\
\hline & \multirow{2}{*}{ FL } & 0.25 & - & $2.5 \pm 0.7$ & $2.5 \pm 0.7$ \\
\hline & & 0.50 & - & $6.0 \pm 1.4$ & $6.0 \pm 1.4$ \\
\hline & \multirow{2}{*}{ FSL } & 0.25 & - & $1.5 \pm 0.7$ & - \\
\hline & & 0.50 & - & $4.5 \pm 0.7$ & $1.5 \pm 0.7$ \\
\hline
\end{tabular}

Information: - = No inhibition zone was detected

besaran diameter zona hambat yang terbentuk pada uji antibakteri yaitu: diameter zona hambat 0-3 $\mathrm{mm}$ (lemah), 3-6 $\mathrm{mm}$ (sedang) dan $>6 \mathrm{~mm}$ (kuat).

Zona hambat tertinggi terdapat pada perlakuan FL konsentrasi $0,50 \mathrm{mg} / \mu \mathrm{L}$ dengan lama waktu fermentasi 48 jam (Tabel 2). Zona hambat tersebut digolongkan ke dalam kategori sedang. Hasil tersebut masih jauh lebih rendah dibandingkan dengan kontrol kloramfenikol yang memiliki zona hambat terhadap E. coli $(16 \pm 1,4 \mathrm{~mm})$ dan $S$. aureus $(16,5 \pm 0,7 \mathrm{~mm})$ pada konsentrasi $0,015 \mathrm{mg} /$ " $\mu \mathrm{L}$ " . Aktivitas antibakteri yang dihasilkan hidrolisat protein pada penelitian ini masih lebih lemah dibandingkan dengan aktivitas antibakteri hidrolisat protein ikan sardin yang dilaporkan oleh Jemil et al. (2014), yaitu memiliki zona hambat terhadap $E$. coli $(12 \pm 2,0 \mathrm{~mm})$ dan $S$. aureus $(16 \pm 1,0 \mathrm{~mm})$ pada konsentrasi $0,2 \mathrm{mg} / \mu \mathrm{L}$.

Aktivitas antibakteri yang terjadi pada perlakuan FL diduga bukan berasal dari peptida bioaktif, melainkan berasal dari senyawa asam organik yang dihasilkan bakteri L. plantarum SK (5) selama fermentasi. Hal tersebut didasari pada perlakuan FL yang tidak mengalami penguraian protein selama fermentasi (Gambar 1), selain itu pada perlakuan FL juga terjadi peningkatan total asam tertirasi paling tinggi selama fermentasi yang berakibat pada penurunan $\mathrm{pH}$ hidrolisat protein hingga mencapai $\mathrm{pH}$ 4 (Tabel 1). Desniar (2012) menyatakan bahwa bakteri L. plantarum SK (5) mampu menghasilkan senyawa antibakteri berupa asam laktat. Alakomi et al. (2000) menyatakan bahwa sifat antimikrob dari asam laktat dikarenakan rendahnya $\mathrm{pH}$. Asam laktat pada $\mathrm{pH} 4$ dapat menyebabkan gangguan pada permeabilitas membran luar bakteri Escherichia coli, Pseudomonas aeruginosa dan Salmonella enterica. Ross et al. (2002) menambahkan bahwa pengaruh antimikroba dari asam organik umumnya mengganggu potensial membran sel, menghambat transpor aktif, mengurangi $\mathrm{pH}$ intraseluler dan penghambatan bermacam-macam fungsi metabolik. Asam organik mempunyai aksi yang luas dan dapat menghambat bakteri Gram-positif dan Gram-negatif, khamir dan kapang.

\section{KESIMPULAN}

Hidrolisat protein perlakuan FS dan FSL mengalami penurunan aktivitas antioksidan seiring bertambahnya waktu fermentasi, sedangkan pada hidrolisat protein perlakuan FL tidak terjadi perubahan aktivitas antioksidan setelah fermentasi. Aktivitas antibakteri tertinggi dihasilkan oleh hidrolisat protein perlakuan FL pada konsentrasi 0,5 $\mathrm{mg} / \mu \mathrm{L}$ dengan lama fermentasi $48 \mathrm{jam}$. Zona hambat yang terbentuk tergolong sedang.

\section{DAFTAR PUSTAKA}

Alakomi HL, Skytta E, Saarela M, Mattilasandholm T, Latva-kala K, Helander IM. 
2000. Lactic acid permeabilizes gram negative bacteria by disrupting the outer membrane. Appl Environ Microbiol. 66: 2001-2005.

Baehaki A, Lestari DW, Romadhoni RA. 2015. Hidrolisis protein ikan patin menggunakan enzim papain dan aktivitas antioksidan hidrolisatnya. Jurnal Pengolahan Hasil Perikanan Indonesia. 3(18): 230-239.

Bledsoe GE, Bledsoe CD, Rasco B. 2003. Caviars and fish roe products. Critical Review in Food Science and Nutrition. 43(3): 317-356.

[BSN] Badan Standardisasi Nasional.2006.SNI 01-2332.3-2006. Cara Uji MikrobiologiBagian 3: Penentuan Angka Lempeng Total (ALT) Pada Produk Perikanan. Jakarta (ID): Badan Standardisasi Nasional.

Chalamaiah M, Jyothirmayi T, Diwan PV, Kumar BD. 2015. Antioxidant activity and functional properties of enzymatic protein hydrolysates from common carp (Cyprinus carpio) roe (egg). Journal Food Science Technolgy. 52(9): 5817-5825.

Chalamaiah M, Kumar B, Hemalatha R. Jyothirmayi T. 2012. Fish protein hydrolysates: Proximate composition, amino acid composition, antioxidant activities and applications: a review. Food Chemistry. 135: 3020-3038.

Desniar. 2012. Karakteristik bakteri asam laktat dari produk fermentasi ikan (bekasam) [tesis]. Bogor (ID): Institut Pertanian Bogor.

Holo H, Nilssen, Ness IF. 1991. Lactococcin A, a new bacteriocin from Lactococcus lactis subsp. cremoris: isolation and characterization of the protein and its gene. Journal of Bacteriology.173(12): 3879-3887.

Intarasirisawat R, Benjakul S, Visessanguan W. 2010. Chemical compositions of the roes from skipjack, tongol and bonito. Food Chemistry. 124: 1328-1334

Intarasirisawat R, Benjakul S, Visessanguan W, Wu J. 2012. Antioxidative and functional properties of protein hydrolysate from defatted skipjack (Katsuwonous pelamis) roe. Food Chemistry. 135(4): 3039-3048.

Intarasirisawat R, Benjakul S, Visessanguan W,
Wu J. 2014. Effects of skipjack roe protein hydrolysate on properties and oxidative stability of fish emulsion sausage. Food Science and Technology. 58: 280-286.

Jemil I, Jridi M, Nasri R, Ktari N, Salem RBS, Mehiri M, Hajji M, Nasri M. 2014. Functional, antioxidant and antibacterial properties of proteinhydrolysates prepared from fish meat fermented by Bacillus subtilis A26. Process Biochemistry.30: 1-10.

Kabadjova-Hristova P, Bakalova S, Gocheva B, Moncheva P. 2006. Evidence for proteolytic activity of Lactobacilli isolated from kefir grains. Journal of Biotechnology. 20(2): 89-94.

Kim SJ, Kim S. 2007. Purification and characterization of antioxidant peptide from hoki (Johnius belengerii) frame protein by gastrointestinal digestion. Journal of Nutritional Biochemistry. 18(1): 31-38.

[KKP] Kementrian Kelautan dan Perikanan. 2015. Kelautan dan Perikanan dalam Angka Tahun 2015. Jakarta (ID): Kementrian Kelautan dan Perikanan.

Klompong V, Benjakul S, Kantachote D, Shahidi F. 2007. Antioxidative activity and functional properties of protein hydrolysate of yellow stripe trevally (Selaroides leptolepis) as influenced by the degree of hydrolysis and enzyme type. Food Chemistry. 102: 1317-1327.

Kristinsson HG, Rasco BA. 2000. Biochemical and functional properties of Atlantic salmon (Salmo salar) muscle proteins hydrolyzed with various alkaline proteases. Journal of Agricultural and Food Chemistry. 48(3): 657-666.

Kurniati N, Mubarik NR, Desniar. 2015. Optimization of production of protease Lactobacillus plantarum SK (5) from bekasam with response surface methodology. Journal of Biotechnology.12(2): 123-130.

Lee YC, Kung HF, Huang YL, Wu CH, Huang YR, Tsai YH. 2016. Reduction of biogenic amines during miso fermentation by Lactobacillus plantarum as a starter culture. Journal of Food Protection. 79(9): 1556-1561. 
Luo HY, Wang B, Li ZR, Chi CF, Zhang QH, He GY. 2012. Preparation and evaluation of antioxidant peptide from papain hydrolysate of Sphyrna lewini muscle protein. Food Science Technology. 51: 281288.

Maier RM, Pepper IL, Gerba CP. 2009. Environmental Microbiology. London (UK): Academic Press, Elsevier.

Molyneux P. 2004. The use of the stable free radical diphenylpicrylhydrazil (DPPH) for estimating antioxidant activity. Journal Science Technolgy. 26(2): 211-219.

Najafian L dan Babji AS. 2012. A review of fishderived antioxidant and antimicrobial peptides: their production, assessment, and applications. Peptides. 33: 178-185.

Nurhayati T, Salamah E, Cholifah, Nugraha R. 2014. Optimasi proses pembuatan hidrolisat jeroan ikan kakap putih. Jurnal Pengolahan Hasil Perikanan Indonesia. 17(1): 42-52.

Ovissipour M, Kenari AA, Motamedzadegan A, Rasco B, Nazari RM. 2011. Optimization of protein recovery during hydrolysis of yellowfin tuna (Thunnus albacares) visceral proteins. Journal of Aquatic Food Product Technology. 20: 148159.

Pan X, Chen F, Wu T, Tang H, Zhao Z. 2009. The acid, bile tolerance and antimicrobial property of Lactobacillus acidophilus NIT. Food Control. 20(6): 598-602.

Pelczar MJ, Chan ESC. 2008. Dasar-Dasar Mikrobiologi 1. Hadioetomo RS, Imas T, Tjitrosomo SS, Angka SL, Penerjemah. Jakarta (ID): UI-Press. Terjemahan dari: Elements of Microbiology.

Pepper, Ian. Gerba C, Gentry T, Maier R. 2008. Enviromental Microbiology: 2nd Edition. Salt Lake City (US): Academic Press.

Phakde G, Elavarasan K, Shamasundar BA. 2014. Angiotensin I converting enzyme (ace) inhibitory activity and antioxidant activity of fermented fish product ngarias influenced byfermentation period. International Journal of Pharma and Bio Sciences.5(2): 134-142.

Rahajeng M. 2012. Warta ekspor: ikan tuna Indonesia [editorial]. Kementrian Perdagangan Republik Indonesia. 3(6):
9-10.

Rajapakse N, MendisE, Jung WK, Je JY, Kim SK. 2005. Purification of a radical scavenging peptide from fermented mussel sauce and its antioxidant properties. Food Research International.38: 175-182.

Ray B. 2004. Fundamental Food Microbiology. Ed. ke-3. New York (US): CRC Press.

Rieuwpassa FJ, Santoso J, Trilaksani W. 2013. Karakterisasi sifat fungsional kosentrat protein telur ikan cakalang (Katsuwonus pelamis). Jurnal Ilmu dan Teknologi Kelautan Tropis. 5(2): 299-309.

Ross RP, Morgan S, Hill C. 2002. Preservation and fermentation: past, presentand future. International Journal of Food Microbiology. 79(1): 3-16.

Samaranayaka AGP. 2010. Pacific hake (Merluccius productus) fish protein hydrolysates with antioxidative properties [tesis]. Vancouver (CA): University of British Columbia.

Salamah E, Nurhayati T, Widadi IR. 2012. Pembuatan dan karekterisasi hidrolisat protein dari ikan lele dumbo (Clarias gariepinus) mengggunakan enzim papain. Jurnal Pengolahan Hasil Perikanan Indonesia. 15(1): 9-16.

Shirai K, Guerrero I, Huerta S, Saucedo G, Castillo A, Gonzales O, Hall GM. 2001. Effect of initial glucose concentration and inoculation level of lactic acid bacteria in shrimp waste ensilation. Enzyme and Microbial Technology. 28: 446-452.

Torino MI, Limon RI, Martinez-villaleunga C, Makinen S, Pihlanto A,Vidal-valverde C, Frias Juana. 2012. Antioxidant and antihypertensive properties of liquid and solid state fermented lentils. Food Chemistry.136(2): 1030-1037.

Udenigwe CC, Aluko RE. 2011. Chemometric analysis of the amino acid requirement of antioxidant food protein hydrolysates. International Journal of Molecule Science. 12(5): 3148-3161.

Wang NS. 2009. Amino acid assay by ninhidrin colorimetric method [Internet]. [diunduh 2016 Apr 25]. Tersedia pada: https:// terpconnect.umd.edu/ nsw/ench485/ lab3a.htm.

Wu Hui-chun, Chen HM, Shiau CY. 2003. 
Free amino acids and peptides as related to antioxidant properties in protein hydrolysates of mackerel (Scomber austriasicus). Food Research. 36: 949-957

Yin LJ, Pan CL, Jiang ST. 2002. Effect of lactic acid bacterial fermentation on the characteristics of minced mackerel. Journal of Food Science. 67(2): 786-792.

You L, Zhao M, Cui C, Zhao H, Yang B. 2009. Effect of degree of hydrolysis on the antioxidant activity of loach (Misgurnus anguillicaudatus) protein hydrolysates. Innovative Food Science and Emerging Technologies. 10: 235-240. 